\title{
Schools as Antecedents of Teacher Burnout: A Case of Public Sector Schools in Lahore
}

\author{
Faiza Shaheen * \\ Nasir Mahmood ${ }^{* *}$
}

\begin{abstract}
The cascading causes and consequences of teacher burnout also put other elements of school effectiveness under question. To estimate the extent of teachers' involvement and to optimize utilization of school facilities, this research study was undertaken. This study examined the degree of relationship among the aspects of burnout among school teachers and school factors. A representative sample of 424 school teachers (Male=178 and Females=246) was selected by convenient sampling technique. Maslach Burnout Inventory-ES (MBI) was administered to measure the emotional involvement of teachers whereas a self-developed tool assessing present school factors was used to estimate the relationship between emotional state of teachers and workplace facilities (school resources).Data were analyzed by using Mean, SD, and Pearson product moment (r). Results indicated that teachers' internal involvement correspond to the availability of given school facilities. In addition to the knowledge about teachers' involvement on job duties, it was recommended that the ultimate school performance can be improved while keeping the right extent of school facilities. Recommendations on coping strategies at personal level by teachers themselves as well as at school level by administrators were also provided.
\end{abstract}

Key Words: Teachers, school factors, causes, burnout, MBI

\footnotetext{
* Lecturer, University of Education, Bank Road Campus, Lahore

** Professor, Department of Early Childhood and Elementary Teacher Education, Allama Iqbal Open University, Islamabad
} 


\section{Introduction}

Spending on education does not find its priority in our context. An already meager allocation of funds is further subdivided into many heads - salary and other non-productive expenditures getting a lion's share. This arrangement leaves a very small chunk of funds left for upgradation, organizational and structural reforms in education. However, most of these funds are spent on teacher recruitment, their training and capacity building. Despite all efforts like Teacher Recruitment Reforms, Continuous Professional Development (CPD) for teachers in late nineties, Millennium Developmental Goals (MDGs) 2000, establishment of Punjab Education Foundation (PEF) 2004, Punjab Examination Commission (PEC) 2005, and Curriculum Reforms, schools of public sector do not produce results commensurate with the amount of effort and money put in. When compared with the private sector schooling, all tangibles are better scored by the private sector i.e. to include a few are indicators like top positions in exams and better performance in entrance exams for further education etc. Efforts put in by the government to improve the quality of education are school centric yet the school environment cannot agitate teachers for their optimal internal involvement on job. What worse - teachers' conduct patterns reflect, under given school environment, established symptoms of teacher burnout? It is both HR and financial loss if teachers are unable to perform at their maximum that is both mentally and physically after acquiring permanent job status. The anomalies mentioned above call for undertaking this study.

The human nature is not consistent when the question is to perform routine tasks with equal proficiency altogether, and when it comes to the treatment of clients while keeping the engagement high and serving up to the rewarding level on which working professionals are compensated by organization, it creates a feeling of stress that further elaborated in form of draining energy, depression, fatigue, being cynical, impersonal and in operativeness (Saiiari, Moslehi, \&Valizadeh, 2011). Burnout is sensitive to the level of ways one can cope with controls on operating when exposed to stressful feelings. Stress mechanisms are receptive to the quantity of given environmental factors and any in-appropriation in these factors triggers emotional imbalances commensurate with the degree of in-appropriation. Phenomenon of burnout has varying tendencies and has comprehensive definition across service providing professions (Martin, Sass, \& Schmitt, 2012; Barutcu \& Serinkan, 2013). However, among 
those multiple perspectives on the theoretical explanations of burnout, emotional exhaustion (EE), depersonalization (DP), and lack of personal accomplishment (PA) are the mostly accepted progressive degrees and their understanding assures a better assimilation of the phenomenon of burnout(Maslach, 1982). Evidence prevails on the debate of determining the due place of all the three sub factors while describing the occurrence of burnout (Maslach, 2003; Saiiari, Moslehi, \&Valizadeh, 2011).

Job burnout is a problem in many professions, but it is significantly more prevalent in the helping professions. Teachers, as well as administrators, counselors, doctors, nurses, police officers, and lawyers have the additional burden of extreme responsibility for the well-being of others on top of the multitude of stressors that stem from routine job activities (Maslach, 2003; Schaufeli \& Enzmann, 1998; Barutcu \& Serinkan, 2008) The scattered aspects of teaching profession make it stressful and demanding job (Travers \& Cooper, 1993; Schwab, Jackson, \& Schuler, 1986). Evidence from the findings of several studies reveals that while making comparison with other service providing professions, even provided with balanced work place environment, teaching is ranked as more emotionally exhaustive job (Schaufeli \& Enzmann, 1998; Innstrand, Langballe, Falkum, \& Aasland, 2011).

There prevails huge evidence that supports the idea of improving the work environment of people who do people work because the professions in which services are provided to people involve more chances for workers to suffer from burnout (Barutçu \& Serinkan, 2008). The phenomenon of burnout is also associated to draw root causes of other related issues in teaching. Ideally a balanced institutional environment keeps the retention rate of teachers high and reduces the trend of teachers' attrition. The adverse consequences of burnout promote teacher attrition which furthers the chances of loss of resources (Gonzalez, Brown, \& Slate, 2008).

The effects of burnout are not one sided, as the nature of teaching profession itself is so broad, and the role of teachers in the balanced upbringing of students has never left to any question or doubt ever. Productivity does not only reduce during the routine job activities of teachers whereas burnout also damages the performance of people attached with teaching (Christle, Jolivette \& Nelson, 2005). The effort to foster learning and skills among students becomes taxing when teachers are supposed to handle diverse demands of school.

The relationship of factors existing in the school environment with burnout has remained a concern of research for so long (Halbesleben \& Buckley, 2004). Burnout among teachers is observed in several forms 
that teachers work in isolation whenever in classes they alone handle the requirements of the crowd of students, pupil behaviour, less chances of professional development, lack of collegial support, and parental involvement make teaching demanding as well as stress causing job (Cephe, 2010; Fisher, 2011)

\section{Institutional Factors Related to Burnout in Teachers}

The stress causing factors prevail within the workplace of teachers in the forms of bulk of roles and responsibilities to be performed by teachers. The heavy workloads combined with limited resources, long hours, marginal working conditions, and often unreasonable demands from recipients of services, lead to chronic stress work as antecedents of burnout among teachers.

School factors as antecedents of burnout among teachers are categorized as personal factors, administrative factors, and environmental factors.

\section{Personal Factors}

The factors that are related to the choice and preference of individuals with regard to opting teaching as career are personal factors. Certain factors are associated with teaching job and imbalance of these factors causes burnout states among teachers. These include chances of promotion (Ali \& Baloch, 2008), career growth and role conflict (Cordes \& Dougherty, 1993), lack of interest (Fisher, 2011), and work family conflict.

\section{Administrative Factors}

The factors that prevail under the responsibility of administrators of school and likely establish the system within school such as favouritism, politics, management style, autonomy of teacher(Skaalvik \& Skaalvik, 2009), salary and incentives(Gonzalez, Brown, \& Slate, 2008), heavy workload (Cordes \& Dougherty, 1993), job security, supervisory support (Skaalvik \& Skaalvik, 2011) are administrative factors.

\section{Environmental Factors}

The factors related to the social and physical context of the school are environmental factors. Class size, school location and distance, poor facilities, isolation, fear of violence (Xin Ma \& MacMillan,1999), behaviour of colleagues and difficult parents(Skaalvik \& Skaalvik, 2011), poor pupil behaviour (Gonzalez, Brown, \& Slate, 2008; Skaalvik 
\& Skaalvik, 2011), and social support(Pomaki, DeLongis, Frey, Short, \& Woehrle, 2010; Maele \& Houtte, 2012; Skaalvik \& Skaalvik, 2011)determine the range of environmental factors.Most of the visible and concrete facilities are dealt with these factors of schools.

There exists no standard reason of leaving the job as human beings differ in many aspects so the study of institutional factors that are antecedent the job satisfaction or dissatisfaction will be helpful to assess the rate of burnout among teachers. The dimensions of emotional burnout among teachers are related to the extent of school level characteristics such as supportive leadership, dedicated and collegial staff, school wide behaviour management, and effective academic instruction (International Labor Organization, 2005). The way stressful condition of teachers deteriorates the system similarly the outcomes of balanced environment is equally important to the teachers as well as the people attached directly or indirectly with teachers in the form of good performance of teachers and students.

Being economically concerned by government, the public sector schools lack in satisfying the needs and levels of facilities when compared with private schooling, that is tangibly result showing sector in case of providing high achievers. The existence of burnout among teachers will be traced out by determining the extent of relationship that prevails among institutional factors and dimensions of burnout. Government is putting efforts relentlessly and striving to upgrade the system but a baseline is needed to draw the loopholes on the way of quality schooling. This study will assess the contribution of school factors in the progression of burnout among teachers. This knowledge will contribute to device reducing ways of burnout among teachers so to improve the performance of teachers.

\section{Objectives of the Study}

The study was followed by these objectives stated below:

1. To measure the rate of burnout among public school teachers

2. To calculate the levels of emotional burnout of teachers

3. To measure the relationship of the dimensions of burnout with school factors 


\section{Research Questions}

Following were the research questions of the study:

1.1 What is the rate of burnout in its three dimensions as Emotional Exhaustion, Depersonalization, and Personal Accomplishment?

2.1 What are the levels of burnout as low, average, and high in its three dimensions?

3.1 What is the association between school factors and burnout rate of teachers?

3.2 What is the degree of relationship between dimensions of burnout and school factors as personal factors, administrative factors, and environmental factors?

\section{Methodology}

The study followed cross-sectional survey design. Data on the perceived amount of burnout and school facilities were collected through survey.

\section{Participants}

424public school teachers (Male=178 and Females=246) serving at junior, primary, elementary, and secondary school levels were accessed by using convenient sampling technique. After reaching22 public schools, teachers of those schools were approached. Only volunteer teachers became part of this survey study.

Table 1

Number of school teachers at different levels of teaching

\begin{tabular}{llc}
\hline & Level at teaching & No. of School Teachers \\
\hline 1. & Junior & 36 \\
2. & Primary & 18 \\
3. & Elementary & 47 \\
4. & Secondary & 323 \\
\hline & No. of Schools & 22 \\
\hline $\mathrm{N}=424$ & &
\end{tabular}

Most of the teachers of the present study were teaching at secondary level. An SST (Secondary School Teacher) possesses higher academic degree than the ESTs (Elementary School Teacher) and PSTs (Primary School Teacher). When the school environment is less accommodating 
and facilitative for all the teachers, the likely chances of detachment from job increases particularly among those who are high in qualification with already an unfeeling of fit with the job place.

\section{Instruments}

Two instruments were used to collect the data for this study.

\section{Maslach Burnout Inventory}

The burnout inventory developed by Maslach and her colleagues has been used in around 90\% studies related to job burnout (Hastings, Horne, \&Mitchell, 2004; Schaufeli \& Enzmann, 1998). Maslach Burnout Inventory- Educators' Survey (MBI-ES) (Maslach, Jackson, \& Leiter, 1996) was used to know the rate of teachers' burnout among public school teachers in Lahore. The low, moderate and high levels of burnout were determined by the range and number of items in each sub dimension of burnout by Maslach (1982).The MBI-ES comprises of 22 statements measuring the three dimensions of emotional burnout i.e. emotional exhaustion EE, the degree to that teachers feel fatigued, drained and tired in response to the stressors on job ( 9 statements) $(\alpha=0.76)$, depersonalization DP, the extent to that teachers behave inhumane and resentful towards students and colleagues (5 statements) $(\alpha=0.73)$, and reduced personal accomplishments PA is the aspect where the tasks' effectiveness reduces to the level of low achievement among teachers and they create self-doubts regarding fulfillment of job roles ( 8 statements) $(\alpha=0.90)$. The total scale Cronbach alpha's value was $\alpha=0.81$. MBI used 7 point frequency scale ranging from ( 0 never) to ( 6 everyday).

\section{Instrument of School Factors}

In order to collect the information about the available school facilities, a self-developed instrument measuring the school factors was administered. It comprised 70 statements with the Cronbach alpha's value $(\alpha=.788)$. It was validated by taking expert opinion on the relevancy of items from field experts. This instrument asked the information about personal factors (11 statements), administrative factors (31 statements), and environmental factors (28 statements) of schools. The instrument assessed the provision of school facilities that triggers the behavior of detachment from job. 


\section{Data Collection}

Teachers were approached with the permission of school principals. Both questionnaires were combined at one place in order to collect both set of information of burnout rate and school facilities from same school teachers. Teachers were given adequate time to complete the survey in the presence of researcher.

\section{Data Analysis}

Descriptive statistics were used to identify the state and levels of burnout among teachers. Correlation analysis was applied to measure relationship among dimensions of burnout and school factors by using Statistical Package for Social Sciences SPSS version 16. Results are reported in the following tables.

Table 2

Descriptive Statistics of the state of emotional burnout of teachers

\begin{tabular}{llll}
\hline Dimensions of Emotional Burnout & No. of items & $\mathrm{M}$ & $\mathrm{SD}$ \\
\hline Emotional Exhaustion (9-54) & 9 & 15.72 & 9.790 \\
Depersonalization (5-30) & 5 & 6.17 & 6.041 \\
Personal Accomplishment (8-40) & 8 & 23.08 & 13.005 \\
\hline $\mathrm{N}=424$ & &
\end{tabular}

Table 2 showed the division of three dimensions of burnout as Emotional Exhaustion, Depersonalization, and Personal Accomplishment scores. The mean score of each dimension of emotional burnout indicates the existence of burnout among teachers. The mean score of Emotional Exhaustion $\left(\mathrm{M}_{\mathrm{EE}}=15.72, \mathrm{SD}=9.790\right)$ showed the existence of weariness, fatigue, stress, frustration, and the feel of being expended at finishing the task day. The mean score of depersonalization $\left(\mathrm{M}_{\mathrm{DP}}=6.17, \mathrm{SD}=6.041\right)$ indicates the degree to that teachers treat students in dehumanized ways whereas the mean score of Personal Accomplishment $\left(\mathrm{M}_{\mathrm{PA}}=23.08\right.$, $\mathrm{SD}=13.005$ ) showed the extent of completion of tasks successfully on job. 
Table 3

Frequency distribution of burnout score of teachers

\begin{tabular}{lll}
\hline Total Burnout & Frequency & $\%$ \\
\hline$<=34.49$ & 141 & 33.3 \\
$34.50-55.00$ & 147 & 34.7 \\
$55.01+$ & 136 & 32.1 \\
\hline$N=424 \%=$ Percentage of respondents & &
\end{tabular}

$\mathrm{N}=424, \%=$ Percentage of respondents

Table 3 indicates the frequency distribution of the scores of burnout of teachers into three proportions including three dimensions of burnout (cumulatively). The occurrence of burnout in the breakdown of respondents $(141,147$, and $136=424$ teachers) shows that larger number of teachers (34.7\%) experienced burnout at medium range (34.50 $55.00)$ than the other almost equal $(=\sim)$ proportions of teachers experiencing burnout whereas the total scores of burnout (instead of considering any dimension of burnout (EE, DP, PA) as separate) measured the emotional burnout in response to stressors at schools among teachers.

Table 4

Descriptive Statistics of the levels of emotional burnout of teachers

\begin{tabular}{|c|c|c|c|c|c|c|c|c|c|c|c|c|}
\hline \multirow{2}{*}{$\begin{array}{l}\text { Levels of } \\
\text { Burnout }\end{array}$} & \multicolumn{4}{|c|}{$\mathrm{EE}$} & \multicolumn{4}{|c|}{$\mathrm{DP}$} & \multicolumn{4}{|c|}{ PA } \\
\hline & $\begin{array}{l}\text { Ran } \\
\text { ge }\end{array}$ & $\mathrm{N}$ & $\begin{array}{l}\text { Mea } \\
n\end{array}$ & SD & $\begin{array}{l}\text { Ran } \\
\text { ge }\end{array}$ & $\mathrm{N}$ & $\begin{array}{l}\text { Mea } \\
n\end{array}$ & SD & $\begin{array}{l}\text { Ran } \\
\text { ge }\end{array}$ & $\mathrm{N}$ & $\begin{array}{l}\text { Mea } \\
n\end{array}$ & SD \\
\hline Low & $\begin{array}{l}(0- \\
16)\end{array}$ & $\begin{array}{l}25 \\
1\end{array}$ & 9.11 & $\begin{array}{l}4.0 \\
05\end{array}$ & $(0-8)$ & $\begin{array}{l}30 \\
1\end{array}$ & 2.88 & $\begin{array}{l}2.5 \\
95\end{array}$ & $\begin{array}{l}(0- \\
30)\end{array}$ & $\begin{array}{l}30 \\
2\end{array}$ & $\begin{array}{l}16.1 \\
0\end{array}$ & $\begin{array}{l}6.7 \\
99\end{array}$ \\
\hline Moderate & $\begin{array}{l}(17- \\
26)\end{array}$ & $\begin{array}{l}11 \\
2\end{array}$ & $\begin{array}{l}20.7 \\
1\end{array}$ & $\begin{array}{l}3.0 \\
62\end{array}$ & $\begin{array}{l}(9- \\
13)\end{array}$ & 61 & $\begin{array}{l}10.7 \\
1\end{array}$ & $\begin{array}{l}1.4 \\
75\end{array}$ & $\begin{array}{l}(31- \\
36)\end{array}$ & 49 & $\begin{array}{l}33.5 \\
4\end{array}$ & $\begin{array}{l}1.6 \\
22\end{array}$ \\
\hline High & $\begin{array}{l}(27 \\
\text { or } \\
\text { over }\end{array}$ & 60 & $\begin{array}{l}34.0 \\
3\end{array}$ & $\begin{array}{l}5.2 \\
49\end{array}$ & $\begin{array}{l}\text { (14 } \\
\text { or } \\
\text { over }\end{array}$ & 62 & $\begin{array}{l}17.6 \\
3\end{array}$ & $\begin{array}{l}3.2 \\
45\end{array}$ & $\begin{array}{l}\text { (37 } \\
\text { or } \\
\text { over }\end{array}$ & 73 & $\begin{array}{l}44.9 \\
2\end{array}$ & $\begin{array}{l}6.0 \\
34\end{array}$ \\
\hline
\end{tabular}

Table 4 indicates the levels of burnout as low, moderate, and high. The total scores on burnout scale were split into levels by using cut-off points followed by the range given in the manual of MBI (Maslach, Jackson, \& Leiter, 1996). 251 school teachers were identified as having low level of Emotional Exhaustion ( $\operatorname{Low}_{\mathrm{EE}}=251, \mathrm{M}=9.11, \mathrm{SD}=4.005$ ), 301 teachers were having low level of Depersonalization $\left(\operatorname{Low}_{\mathrm{DP}}=301\right.$, $\mathrm{M}=2.88, \mathrm{SD}=2.595$ ), and 302 teachers were having low Personal 
Accomplishment ( $\left.\operatorname{Low}_{\mathrm{PA}}=302, \mathrm{M}=16.10, \mathrm{SD}=6.799\right) .112$ teachers were having moderate level of Emotional Exhaustion (Moderate $\mathrm{EE}_{\mathrm{E}}=112$, $\mathrm{M}=20.71, \mathrm{SD}=3.062$ ), 61 teachers were having moderate level of Depersonalization (Moderate $\mathrm{DP}_{\mathrm{DP}}=61, \mathrm{M}=10.71, \mathrm{SD}=1.475$ ), and 49 teachers were identified having moderate level of Personal Accomplishment (Moderate $\mathrm{PA}_{\mathrm{PA}}=49, \mathrm{M}=33.54, \mathrm{SD}=1.622$ ). High level of Emotional Exhaustion was identified among 60 teachers $\left(\mathrm{High}_{\mathrm{EE}}=60\right.$, $\mathrm{M}=34.0, \quad \mathrm{SD}=5.24$ ), high Depersonalization among 62 teachers $\left(\right.$ High $\left._{\mathrm{DP}}=62, \mathrm{M}=17.6, \mathrm{SD}=3.24\right)$, and high Personal Accomplishment was found among 73 teachers $\left(\mathrm{High}_{\mathrm{PA}}=73, \mathrm{M}=44.9 .0, \mathrm{SD}=6.03\right)$. It is concluded that teachers have varied levels of burnout those are low, moderate, and high.

Table 5

Correlation between Burnout scores and School Factors

\begin{tabular}{llllll}
\hline Variables & $\mathrm{N}$ & $\mathrm{M}$ & $\mathrm{SD}$ & r-value & Sig. \\
\hline Burnout Score & 424 & 44.96 & 19.037 & .175 & .000 \\
School Factors & 424 & 201.53 & 30.749 & & \\
\hline${ }^{* *}$ Correlation is significant at the 0.05 level & & & & &
\end{tabular}

Table 5 shows that relationship between burnout scores and school factors was investigated by using Pearson product-moment correlation coefficient. There was positive relationship between total burnout scores and school factors ( $\mathrm{r}=.175, \mathrm{n}=424, p<.005)$. It is concluded that there is positive relationship between emotional burnout of teachers and school factors.

Table 6

Pearson Product-Moment Correlation between school factors and burnout

\begin{tabular}{|c|c|c|c|c|c|c|c|}
\hline Variables & $M$ & SD & $\mathrm{N}$ & $\mathrm{EE}$ & DP & PA & $\begin{array}{l}\text { Total } \\
\text { burnout }\end{array}$ \\
\hline 1.Personal Factors & 32.59 & 7.399 & 423 & $.102^{\star \star}$ & $.120 * \star$ & -.18 & .079 \\
\hline 2.Admin Factors & 89.44 & 15.807 & 424 & .76 & .091 & .093 & $.132^{\star *}$ \\
\hline 3.Envir Factors & 79.25 & 15.485 & 423 & .053 & $.195^{\star *}$ & $.136^{* *}$ & $.182^{\star *}$ \\
\hline
\end{tabular}


The relationship between school factors and dimensions of burnout was investigated by using Pearson product-moment correlation coefficient. There was relationship between Personal factors and Emotional exhaustion ( $\mathrm{r}=.102, \mathrm{n}=421, p<.005)$, personal factors and Depersonalization $(\mathrm{r}=.120, \mathrm{n}=423, p<.005)$, Administrative factors and total burnout score $(\mathrm{r}=.132, \mathrm{n}=423, p<.005)$, environmental factors with Depersonalization $(\mathrm{r}=.195, \mathrm{n}=423, p<.005)$, environmental factors with Personal Accomplishment $(\mathrm{r}=.136, \mathrm{n}=423$, $p<.005)$, and Environmental factors with total burnout score $(\mathrm{r}=.182, \mathrm{n}$ $=423, p<.005$ ). It is concluded that school factors as personal factors, administrative factors, and environmental factors are correlated differently with the three dimensions of burnout among teachers.

\section{Discussion}

The study was guided by main objective of measuring the rate of burnout among school teachers and their scores on burnout inventory were analyzed by using descriptive statistics. The mean score and standard deviation scores showed teachers with the prevalence of burnout in its three dimensions as emotional exhaustion, depersonalization, and lack of personal accomplishments of job tasks.

The knowledge about the prevalence of burnout rate among public school teachers worked as rudiments of running the further analysis. One of the purposes of the study was to measure the levels of burnout among school teachers thereby assessing the levels of burnout was done by following the range of scores given by Maslach (Maslach, Jackson, \& Leiter, 1996). The knowledge of levels of burnout is important to understand the progression of burnout as each dimension proceeds to the next dimension. Most of the teachers were found with low level of emotional exhaustion, depersonalization, and personal accomplishment. Moderate and high levels of EE, DP, and PA were also reported. It implies to make schools stress free environments.

In order to determine the degree of relationship of school factors and burnout rate, the burnout rates of teachers and the school factors were correlated. Since the school factors prevail in many forms. Sometimes the demographic characteristics of teachers contribute enough in the prevalence of burnout (Dombovskis, Guseva, \& Murasovs, 2011; Maele \& Houtte, 2012) whereas the personal factors, administrative, and environmental factors also become a cause of burnout among school teachers. The finding of the present study determined some degree of relationship in available school facilities and burnout rate of teachers. It 
is due to the nature of teaching profession that is dependent upon the given job resources at schools. The more school is facilitative and provides necessary facilities, the chances of burnout among teachers there decrease. It implies school authorities to keep school facilities commensurate to the level of requirements of teachers. When teachers are given with the adequate level of facilities it does not only keep the performance of teachers high, but the morale of other people attached with schools also increases (Christle, Jolivette \& Nelson, 2005).

The inverse nature of the phenomenon of burnout makes it easy to understand and remediate. Besides putting several checks on the performance of teachers, the available resources and ease at workplace provided by schools are sufficient to ensure the high performance of teachers (Pietarinen, Pyhalto, Soini, \& Salmela-Aro, 2013). When the personal factors, administrative factors, and environmental factors were separately correlated with three dimensions of burnout, it resulted in showing varied degrees of relationship. Personal factors were highly correlated with emotional exhaustion and depersonalization. It is due to the expectations of teachers from their jobs in form of being given with ease, chances of professional development, and assigned with only relevant work in schools. The more the personal factors are in favor of teachers, the less they feel emotionally detached and depersonalized at job. It implies to create chances of training for teachers to cope with stress at personal levels so to make their jobs less exhaustive. Administrative factors were found correlated with the overall score of burnout of teachers. This degree of relationship signifies the value of adequate resources within school system that discourages exhaustion and encourages fulfillment of tasks. By providing defined roles on job, teachers perform at their best(Gonzalez, Brown, \& Slate, 2008). The environmental factors were found low correlated to depersonalization, personal accomplishment and to overall burnout scores. The low relationship with environmental factors indicates some improvement in the schools at public sector, but yet the need of making schools as resourceful places exist where the issues of lack of facilities do not prevail.

The results are also in consent with previous studies (Halbesleben \& Buckley, 2004). School facilities and characteristics of teachers are contributing factors in the prevalence of burnout rate among school teachers. Studies that determine the position of factors that cause burnout provide foundation knowledge on devising remedial ways to stress and burnout. The way the disequilibrium of school facilities cause teachers to burnout similarly a balanced school environment with optimum 
availability of facilities provide minimal chances of burnout of teachers there. The availability of resources within schools is indigenous but yet it has been subjected to research through model testing by measuring school components with burnout rates (Hakanen, Bakker, \& Schaufeli, 2006;Parker, Martin, Colmar, \& Liem, 2012). It is suggested for future study to predict the prevalence of burnout on the base of available school facilities to further upgrade school systems.

\section{References}

Ali, N., \& Baloch, Q. B. (2008). Impact of job satisfaction on turnover intention: An empirical evidence. Journal of Managerial Sciences, 2341. BarutçE., Serinkan C., (2008). Gunumuzunonemli Sorunlarından Biri Olarak Tükenmişlik Sendromuve Denizli'deYapılan Bir Araştırma, Ege Academic Review,8(2),541-561

Barutcu, E., \& Serinkan, C. (2013). Burnout syndrome of teachers: An empirical study in Denizli in Turkey. Social and Behavioral Sciences, 318-322.

Cephe, P. T. (2010). A study of the factors leading english teaches to burnout. Journal of Education, 25-34.

Christle, C, A., Jolivette, K., \& Nelson, C, M. (2005).Breaking the school to Prison Pipeline. Identifying school risk and protective factors for Youth Delinquency. Exceptionality. Vol 13 (2), p 69-88.

Cordes, C. L., \& Dougherty, T. W. (1993). A review amd an integration of research on job burnout. Academy of Management Review, 18(4), 621-656.

Dombovskis, V., Guseva, S., \& Murasovs, V. (2011). Motivation to work and the syndrome of professional burn-out among Teachers in Latvia. Social and Behavioral Sciences, 98-106.

Fisher, M. H. (2011). Factors Influencing Stress, Burnout, and Retention of Secondary Teachers. Current Issues in Education, 14(1). Retrieved from http://cie.asu.edu/ 
Gonzalez, L., Brown, M. S., \& Slate, J. R. (2008). Teacher who left the teaching profession: A qualitative understanding. The Qualitative Report, 13(1), 1-11.

Halbesleben, J. R. B., \& Buckley, M. R. (2004).Burnout in organizational life. Journal of Management, 30(6), 859-879.

Hastings, R. P., Horne, S., \& Mitchell, G. (2004). Burnout in direct care staff in intellectual disability services: A factor analytic study of the Maslach burnout inventory. Journal of Intellectual Disability Research, 48, 268-273.

Hakanen, J. J., Bakker, A. B., \& Schaufeli, W. B. (2006). Burnout and work engagement among teachers. Journal of School Psychology, 495-513.

Innstrand, S. T., Langballe, E. M., Falkum, E., \& Aasland, O. G. (2011).Exploring within and between gender differences in burnout: 8 different occupational groups. International Archives of Occupational and Environmental Health, 84(7), 813-824.

International Labour Organization. (2005). Teachers for the Future: Meeting Teacher Shortages to Achieve Education For All. South Africa: A Publication of the department of Education.

Maele, D. V., \& Houtte, M. V. (2012). The role of teacher and faculty trust in forming teachers' job satisfaction: Do years of experience make a difference? Teaching and Teacher Education, 879-889.

Martin, N. K., Sass, D. A., \& Schmitt, T. A. (2012). Teacher efficacy in student engagement, instructional management, student stressors, and burnout: A theoretical model using in-class variables to predict teachers' intent-to-leave. Teaching and Teacher Education, 546-559.

Maslach, C. (1982) Burnout: The cost of caring. Englewood Cliffs, NJ: Prentice Hall.

Maslach, C. (2003). Job burnout: New directions in research and intervention. Current Directions in Psychological Science, 12, 189192. 
Maslach, C. \& Jackson, S. E. \& Leiter, (1996).The measurement of experienced burnout. Journal of Occupational Behaviour, 2, 99-113.

Pomaki, G., DeLongis, A., Frey, D., Short, K., \& Woehrle, T. (2010). When the going gets nkmtough: Direct, buffering and indirect effects of social support on turnover intention. Teaching and Teacher Education, 1340-1346.

Pietarinen, J., Pyhalto, K., Soini, T., \& Salmela-Aro, K. (2013). Reducing teacher burnout: A socio-contextual approach. Teaching and Teacher Education, 62-72.

Parker, P. D., Martin, A. J., Colmar, S., \& Liem, G. A. (2012). Teachers' workplace well-being: Exploring a process model of goal orientation, coping behavior, engagement, and burnout. Teaching and Teacher Education, 503-513.

Schaufeli, W. B., \& Enzmann, D. (1998). The Burnout Companion to Study \& Practice: A Critical Analysis. Philadelphia: Taylor \& Francis.

Saiiari, A., Moslehi, M., \& Valizadeh R. (2011). Relationship Between Emotional Intelligence And Burnout Syndrome In Sport Teachers Of Secondary Schools, Procedia Social and Behavioral Sciences 15 ,1786-1791

Schaufeli, W. B., \& Enzmann, D. (1998). The burnout component to study and practice. London: Taylor \& Francis.

Schwab, R. L., Jackson, S. E., \& Schuler, R. S. (1986). Educator burnout: sources and consequences. Educational Research Quarterly, 10(3), 14-30.

Skaalvik, E. M., \& Skaalvik, S. (2011). Teacher job satisfaction and motivation to leave the teaching profession: Relations with school context, feeling of belonging, and emotional exhaustion. Teaching and Teacher Education, 1029-1038.

Skaalvik, E. M., Skaalvik, S. (2009). Does school context matter? Relations with teacher burnout and job satisfaction. Teaching and Teacher Education, 518-524. 
Travers, C. J., \& Cooper, C. L. (1993). Mental Helath, job satisfaction and occupational stress among UK teachers. Work and Stress, 7(3), 203-219.

Xin Ma., \& MacMillan. R. B., (1999). Influences of Workplace Conditions on Teachers' Job Satisfaction. The Journal of Educational Research, 93:1, 39-47, DOI: 10.1080/00220679909597627.

Received on: January 03, 2016

Revised on: May 19, 2016

Accepted on: June 01, 2016 